\title{
Enhancing Brand Equity through Sustainability: Waste Recycling
}

\author{
Suraksha Gupta \\ Senior Lecturer \\ Kent Business School \\ University of Kent, UK \\ Email: suraksha.gupta@gmail.com
}

\begin{abstract}
Unlike many of existing research studies that explain reverse marketing from a purchasing perspective, this study recognises it as an honest effort made by managers aiming to promote sustainability by purposefully managing waste and discusses the spill over effect of their initiatives on brand equity. It argues that efficient recycling of products through reverse marketing by a brand demonstrates its sincere intent to adopt sustainable business practices and enhances its equity in the marketplace. A business-to-business viewpoint has been used to combine knowledge about waste recycling and management through reverse marketing based on the unpretentious operations and management practices. The propositions reflect on the criticality of engaging business customer firms in a procedural mechanism of recycling for increase in brand equity as the success of reverse marketing. A comprehensive adoption of an initiative like waste management through reverse marketing by a brand highlights how sustainability initiatives can create value for the customers of the brand and ultimately drive brand equity.
\end{abstract}

Keywords: Sustainability, Reverse Marketing, Brand Value, Brand Equity and India. 


\section{Introduction}

European Union (EU) regulations hold international sellers responsible for honestly promoting sustainability through recovery and disposal of waste (Salzman, 1997). The waste management framework identified by EU also highlights role of buyer-seller agreements in improving effectiveness of waste management processes by reflecting on the economic and social viability of recyclable products (Rosen et al. 2002; Yia-Mella et al. 2014). Simultaneously, satisfying regulatory requirements related to management of waste in an international context through nonregulatory business-to-business (B2B) agreements between buyers and sellers with due diligence demonstrates the sensitivity of a manufacturer to critical issues related to sustainability (Chave, 2003; Quayle, 2002; Lehr et al., 2013). But, the gap between aspirations of two firms can influence their honest adoption of sustainability oriented business practices, thereby eroding the brand equity. Infamous exit of IBM out of Indian market in 1978 is an appropriate example of a failure of business relationship due to non-compliance and non-transparency in its recycling practices (Sharma, 2011). As explained by Sharma (2011), IBM was accused of supplying old technology and refurbished hardware in Indian market at very high prices. However, IBM returned to India through a business-to-business agreement in 1992. Extant marketing literature reflects on such agreements as relationship between two firms managed for mutual benefits recognised as value earned by both from relationship (Handfield and Bechtel, 2002; daCruz et al. 2014).

The need for value creation from sustainability-driven business practices for buyers encourages sellers to consider activities like returns, waste and scrap management from a commercial viewpoint (Meade et al., 2007; Long, 2008; Linton et al. 2007; Hazen et al. 2014). Embedding business practices into sustainability principles helps companies to reap the benefits from value generated through B2B engagements and leads to superior commercial performance 
while developing perceptions of competitiveness (Schau et al., 2009). Previous marketing researchers have taken a macro view of the value contributed by sustainability initiatives to buyer-seller agreements as superior business performance (Gupta and Kumar, 2012; Wei et al. 2014) and have failed to adopt a micro view of sustainability-oriented business practices when embedded into a B2B marketing context. Existing studies such as Sharma (2002); Sharma and Sheth (2004) and Blenkhorn and Banting (1991) that focus on reverse marketing also do not explain the kind of support that marketing requires from operations in order to create value for two firms engaged with each other for business and reflect on the process as a sustainability initiative.

Current understanding about how to approach sustainability as an honest initiative that engages both marketing and operations is quite negative and is based on the arguments that threaten managers by describing the adverse effects of the non-adoption of sustainability-based business practices. Digressing from traditional understanding that instils fear, this study aims to highlight a sustainability orientation as an opportunity that encourages managers to consider its integration into their business practices. This research synthesizes concepts as mainly complementary yet different business functions to propose that a sustainability-oriented activity like recycling, when adopted through reverse marketing, can create brand value that benefits both the buyer and seller. As recycling can be considered as the recovery of different types of products that are rare, precious or common, the focus of this study is on recycling as the reconditioning of used products for resale. The process from initiation till the end, i.e. from acquisition to the resale of recycled products, is conceptualised to understand how two firms can benefit individually. The conceptual framework (Figure 1) provides a comprehensive representation of marketers' perspectives of sustainability initiatives and the relationship with the 
brand. This study highlights how buyer-seller agreements aimed at recycling can generate brand value and influence brand equity in a way that initiates a cyclic causality between these two constructs. The review reflects on current business practices and underpins them into current theories to make research propositions. Before concluding, a discussion on the implications and limitations of the study provides guidance to practitioners and researchers.

\section{Reverse Marketing for Recycling}

Reverse marketing is a concept that was initiated by companies selling transformers and power generators, and later pioneered by technology brands such as IBM or Xerox and automobile brands such as Hyundai (Figure 2). Liang (2006) used the theory of reverse marketing to systematically explain the importance of B2B relationships in implementing complex business practices by a manufacturer. Managers increasingly realize that reverse marketing can facilitate the achievement of sustainability objectives by integrating the different functions performed by their firm to achieve business objectives for reducing, recycling and reusing waste or scrap (Faisal, 2010; Sheth et al., 2011). The operational viewpoint of sustainability recommends an efficient and eco-friendly use of resources available for improving the outcome of actions taken by managers (Rese, 2006), and marketing scholars support the idea of using sustainability for developing a positive brand image and creating brand differentiation (Sarkar, 2012; Fraj et al., 2013; Seshadri, 2013). Considering sustainability as an important parameter for assessing the eco-friendly practices of a company, managers attempt to take up resource intensive special initiatives such as recycling through activities like reverse marketing to reflect on their sustainability-oriented business practices (Crittenden et al., 2011). Other studies have explained 
the role of buyer-seller agreements in enhancing the capability of a manufacturer using a distribution network to manage recycling through reverse marketing (Norek, 2003).

The concept of recycling was defined by Carter and Ellarm (1998) as a function of operations management that allows the efficient use of returns, waste and scrap after reprocessing. The primary idea of the function is to reduce waste and has been exercised differently by various firms through practices that allow them to reuse disposed materials with or without any reprocessing, e.g. the reuse of glass bottles by companies such as Coca Cola or Pepsico, and hangers by retailers such as Marks and Spencer. Examples of reuse can also be found in the practices of manufacturers of wires and cables that collect old reels and spools when they make new deliveries to telephone and cable companies, or companies that reuse specifically designed pallets or crates designed specifically for peculiar components. Recycling after reprocessing is practiced by companies that produce cardboard or white paper from mixed paper recycling but not metal recycling. Waste management-related activities are dependent on business functions that involve traditional supply chain practices from the opposite direction and engage the manufacturer, distributor, resellers and retailers into activities that lead to the recycling of the disposed products (Mai et al., 2012; Guide et al., 2003; Tixier, 2003). These practices advocate the adoption of an ecological attitude and a social conscience approach for converting used products into fully functional products (Seuring et al., 2008; Chaerul et al. 2014). Using a resource-based view, Mai et al. (2012) empirically investigate the concept of recycling and identify returns management orientation, internal collaboration and information support to be predictors of reverse marketing that ultimately influence the overall performance of the firm. Richey et al. (2005) review resource commitment and innovation as antecedents of reverse marketing adopted for strategic operations management. They also reflect upon the role 
of buyer-seller agreements in facilitating the management of returns to improve the efficiency of reverse marketing.

Reverse marketing is also considered for proactive, multidimensional and strategic purchases by Biemans and Brand (1995), using cost, time and quality as important driving factors. Leenders and Blenkhorn (1988) explain reverse marketing as a function of purchasing that is useful to managers in order to identify potential suppliers who can increase the competitiveness of the manufacturer by participating in controlling product quality and satisfying unmet demands in a marketplace. Pressey et al. (2007) use data collected from purchase managers to discuss reverse marketing as a strategic purchasing activity that places emphasis on the fit between buyers and suppliers based on important issues of quality and delivery. Grewal et al. (2004) apply concepts of reverse marketing to review the dynamics of price and value-related aspects in the virtual domain to understand their influence on the loyalty of customers. Recycled products when offered through reverse marketing can generate value if they have an emotional appeal, operational and functional efficiency, and environmental benefits from a social perspective (Menon and Menon, 1997).

Stock et al. (2002) use survey data from automobile companies to explain how the manufacturers can use the recycling of damaged products, overstocks and incorrect shipments to incorporate value into buyer-seller agreements through activities of reverse marketing. A study conducted by Hunt and Morgan (1996) explains the role of tangibles and intangibles in creating value for market segments through innovative business practices. This study is instead based on the belief that encouraging B2B customers to participate in sustainability initiatives like reverse marketing for waste management requires marketing managers to design the activity as a process that generates value for participants. Therefore, buyer-seller agreements using the resource- 
based view of Høgevold and Svensson (2012) are considered to explain the capability of a manufacturer to adopt reverse marketing tactics as a bottom-up approach, and apply theories of branding as intangible to reflect on the brand value it generates as tangible for B2B customers.

Sustainability-driven Brand Value: Brand value in an industrial context has been explained as the net present value of a brand's capability to create future cash flow for the manufacturer and other firms that participate in its business-related activities to benefit from the ability of the brand to drive the demand of its products (Calderon et al., 1997; Goldfarb et al., 2009; Arruda, 2009). Although sustainability orientation creates value but reduces short-term profitability (Closs et al., 2011; Kumar et al., 2011), brands that use sustainability-based business practices can generate greater opportunities of mutual benefits for all the firms engaged in their business activities (Cox, 2004). Lapierre (2000) empirically validates factors that encourage B2B customers to become engaged in the sustainability-oriented business practices of a brand, and determines profit to be an important feature of brand value that inspires them. Wong and Dean (2009) place emphasis on profit and growth as incentives appropriate for B2B customers who engage themselves in the adoption of a specific business practice, and links the outcomes to their loyalty towards the brand. Therefore, it is important for managers to understand how brands can use reverse marketing for creating opportunities of gains and present it as brand value that encourages B2B customers to participate in its recycling initiatives. Therefore, this study proposes:

Proposition 1: The likelihood of business-to-business customers participating in the waste management initiatives of a brand can be determined by measuring the brand value these initiatives create for the business of the customer firm. 
Sustainability-driven Reverse Marketing: Krikke et al. (2003) introduce and expand the theoretical underpinning of recycling and explain it as a reverse activity that consists of actions related to the forward and backward flow of goods (Carter and Ellarm, 1998). The study by Menon et al. (1999) recommends a blend of marketing and operations to enhance the efficiency of reverse actions when adopted for sustainability orientation. The business practices of international automobile brands such as Maruti Suzuki in India clearly reflect on the role of B2B customers in facilitating the amalgamation of two different functions, i.e. marketing and logistics for sustainability. The B2B customers of Maruti Suzuki participate in its 'True Value' initiative to initiate the backward flow of used and the forward flow of recycled goods. Their participation aids the operational capability of Maruti Suzuki to achieve the objectives of sustainability by recovering recyclable products through its initiative 'True Value'. These B2B customer firms also engage themselves in refurbishing the recovered products to make them reusable for their commercial benefit, which ultimately leads to the efficient management of waste of the branded products (Krikke et al., 2003). Marketing contributes by developing the market demand for refurbished products, thereby creating economic value for actors engaged in the process without increasing carbon footprint (Crittenden et al., 2011). The role of reverse marketing in recycling is to initiate the backward and outward flow of recycled goods (Sirgy and Lee, 2008). Simultaneously, operational efficiency makes the collection and redistribution of old products for refurbishment effortless and meaningful for those companies who undertake to revive them as per the prescribed quality standards and threshold of the brand (Richey et al., 2005). While the current literature discusses reverse marketing as an activity of logistics managed by operations and presents it as a determinant of sustainability (Cruz-Rivera and Ertel, 2009), it does not recognise that the marketing managers are being pushed to ensure the adoption of sustainability- 
oriented business practices for commercial reasons. Recognising this push and the capabilities required adopting sustainability practices like recycling; this research proposes that the engagement of B2B customers in its operations and marketing-related activities can help inexperienced managers in successfully adopting reverse marketing. Therefore, this research proposes:

Proposition 2: The likelihood of waste management initiatives to encourage brand managers for the adoption of reverse marketing will depend upon their effectiveness in engaging business customers in managing the backward flow of used products and the forward flow of recycled products.

The adoption of reverse marketing for managing recycling through $\mathrm{B} 2 \mathrm{~B}$ customers reveals opportunities of profit making for B2B customers based on a decreased cost of selling, minimum cost of the product, and frequent service after sales of old products of the brand (Schiele et al., 2011). However, complexity in the collection, assessment, repair, repackaging, restocking and resupplying of old and used products makes it quite expensive for brands. Although expensive, the management of reverse marketing as a sustainability-oriented initiative that optimises resource utilisation provides opportunities of value creation to brand managers (Seuring et al. 2008; Park et al., 2010).

Reverse Marketing for Brand Value: B2B customer firms make the backward and forward flow of old and used products smooth by facilitating the easy recovery of the old products and the sale of the recycled products of the brand, thereby making reverse marketing manageable (Menon et al. 1999). While B2B customers support brand managers in managing the difficulties of reverse marketing to their target segment by allowing the use of their resources, the buyer-seller engagement between them increases the business scope and size of the market being served by the brand with recycled products (Sharma et al., 2010; Babarinde, 2009). Promotions of the 
recycled products by the brand facilitate the growth of B2B customer firms (Gupta and Malhotra, 2013). While existing research explains how B2B customer firms reduce the complexity of the reverse marketing it fails to explain the kind of value that reverse marketing creates to keep B2B customers engaged in the process. Therefore, the author proposes that:

Proposition 3: The likelihood of waste management initiatives to create brand value for business customers will depend upon the effectiveness of brand managers in identifying how customer firms will benefit from the reverse marketing of recycled products.

Reverse Marketing for Brand Equity: Recycling-based sustainability practices when adopted through reverse marketing create greater opportunities of sales (Sheth, 2011; Freires, 2014). As the quality of the recycled products provided through reverse marketing is perceived to be comparatively lower than new products, Hazen et al. (2011) suggest that companies offering recycled products should compete on traits such as credibility. Recycled products when offered by a brand inculcate the confidence that business customers have in the quality of the product (Sarkar, 2012). Although previous studies have explained the influence of sustainabilityoriented business practices on the business performance of the brand, they have not been able to reflect on the capability of recycled products, when supplied through B2B customers, on capturing the overall equity of the brand in a market. This study expects that appropriate promotions by the brand build the expectations of B2B customers about the market share that recycled products can capture. Therefore, it can be assumed that such features when attached to reverse marketing can encourage B2B customers to become engaged and participate actively in supplying recycled products to its appropriate target segment and thereby increase overall brand equity. Therefore, this study posits that:

Proposition 4: The likelihood of waste management initiatives to drive brand equity in a market depends upon the extent to which business customers engage themselves 
and participate in promoting the recycled products of the brand in the market being served by them.

\section{Brand Value and Brand Equity}

Satisfactory experiences of brand value make B2B customers loyal to the brand and determine the share of the market that a brand can capture as brand equity (Gremler and Brown, 1999). A study conducted by Raggio and Leone (2007) reviews brand value and brand equity as two related but different constructs and explains how the two are different, distinct and unique by explaining that brand value represents what 'brand' means to its internal audience and brand equity describes what 'brand' means to its external audience. The two constructs can be differentiated considering brand value as the usefulness of the brand to the seller, and brand equity as the perceptions of usefulness of the brand to the buyer. As B2B customers consider the ability of a brand to capture a market share as an important criterion before they engage themselves, the creation of brand value and brand equity becomes an iterative and cyclic process to be managed by brand managers (Chaudhuri and Holbrook, 2001).

Reverse Marketing-driven Brand Value for Brand Equity: The adoption of reverse marketing for the creation of brand value requires higher amounts of resources and the integration of marketing efforts with operations-related business activities (Amit and Zott, 2001). An increase in brand value created through reverse marketing when offered to B2B customers influences their salesrelated efforts (Sharma and Sheth, 2004). The benefits received from the sale and service of the resold, recycled or reengineered products creates brand differentiation assessed by B2B customers and encourages them to become engaged in the reverse marketing-related activities of a brand (Gobbi, 2008). Hence, it can be argued that the active engagement of B2B customers in reverse marketing can improve the credibility of a brand in a market and increase the overall 
market share captured by that brand; thereafter positioning the brand as a market leader. Therefore, this study posits that:

Proposition 5: The likelihood of waste management to positively influence brand equity will depend on the brand value assessed by B2B customers as a contribution made by the initiative to their customer base, growth and profitability.

Reverse marketing-driven Brand Equity for Brand Value: Reverse marketing helps brand managers to demonstrate an organisational mind-set of sustainability and engage a larger set of B2B customers actively in their sustainability initiatives such as recycling (Sheth et al. 2011; Keller, 1993). Agreement between B2B customers and the brand for selling recycled branded products depend upon the brand's capability to capture and successfully manage a larger share of the market (Tang, 2010). The brand experiences of B2B customers relating to the benefits they receive from their participation in initiatives like reverse marketing influence their understanding of the brand's ability to contribute value to their business. Therefore, this research argues that:

Proposition 6: The likelihood of brand equity created through reverse marketing to influence the brand value it offers to B2B customers will depend upon the brand's ability to fulfil the commercial agenda of its business customer firms.

\section{Discussion}

The Waste Electrical and Electronic Equipment (WEEE) regulations acknowledge the influence of waste generated by manufacturers on landfills. The directives provided by the Environment Agency specify that the management of waste is a responsibility of the manufacturer that should be fulfilled through the adoption of sustainability-oriented business practices such as recycling. Therefore, firms from different industries attempt to adopt business models that facilitate the reuse of products and reduce waste. The adoption of reverse marketing addresses concerns 
related to sustainability by facilitating the recycling of waste and necessitates a cross-functional approach between marketing and operations (Steenkamp and Hofstede, 2002; Isdell, 2010). A review of the literature presented in the previous section discusses this approach and indicates how such integration when embedded into concepts of branding builds competences for firms in an international market (Sarkar, 2012; Mascarenhans and Koza, 2008).

As buyer behaviour in international industrial markets emphasises upon efficient delivery, technical assistance, service after sales and financial benefits, a state-of-the-art business model for managing reverse marketing enables manufacturers to ensure that $\mathrm{B} 2 \mathrm{~B}$ customers benefit from the demand it derives and processes it involves (Chung et al., 2012; Tixier, 2005). The adoption of reverse marketing allows brands to efficiently address market deficiencies and address technological concerns by controlling the quality of recycled products (Henderson and Venkatraman, 1993). Quality-checked recycled or remanufactured products, offered with brand recognition, improve the profitability for $\mathrm{B} 2 \mathrm{~B}$ customers and increase market penetration for the manufacturer (Olson et al. 2005). Therefore, the sale of recycled products by a brand can build the competences of industrial buyers. The business model adopted by Suzuki's collaboration in India, called Maruti Suzuki of 'True Value' clearly demonstrates how pre-owned cars can be resold successfully using the brand name of a manufacturer i.e. 'Maruti'. As reported by Gupta and Malhotra (2013), through B2B customer engagements Maruti has successfully performed reverse marketing because both the firms benefit from many of activities related to recycling, like acquisition, repair, testing, certification and promotion. These benefits when received in the form of larger share of the consumer market, growth of the company and profit earned are perceived as brand value offered by business customers. Perceptions of business customers 
about superior value offered by a brand through recycling and waste management helps managers of the brand to capture a larger share of the market and increase their brand equity.

Mile and Snow (1978) recommend an entrepreneurial approach to be taken by managers for performing administrative and technical functions to identify market deficiencies and exploit them as new opportunities to be served by the brand through its B2B customers (Slater and Narver, 1995). Porter (1980) argues that value creation based on low cost and high returns leads to differentiation. Existing frameworks that explain value creation for B2B customers may not allow ideas related to the concept of sustainability from both social and commercial perspectives to take a definitive shape (Crittenden et al. 2011; Sheth, 2011). Alternative concepts that are consistent with the agenda of both the manufacturer and customer firms about optimising the use of resources available assert on reducing the overall cost and a balanced approach from which both firms benefit (Parkes and Borland, 2012). An environmental assessment report by EPA reveals that the adoption of business models that incorporate sustainability initiatives into activities such as recycling and reduced transportation has helped brands like LG, Samsung, Sony, Sharp, Sprint and Staples. For example, as reported by Environmental Reporter (2013), LG has been able to improve its greenhouse gas emission by 61,348 metric tons of $\mathrm{CO}_{2}$ and reduced expenses by $\$ 1$ million since December 2012.

Webster (2000) recommends extending the existing frameworks to strategically deal with the challenges faced by managers, and proposes the alignment of organisational activities with marketing to allow firms to successfully address the opportunities available in a marketplace. However, extending the existing frameworks might fail to reflect the current market situation and guide marketing managers to do more with less in an era where preservation is the key. The aim of this study is to reflect on this issue and help managers to identify opportunities to build a 
culture of reuse and recycle by reducing, recovering and refurbishing. The propositions reflect on the ways in which brand managers can engage B2B customers in achieving sustainability orientation in their business processes and initiate an iterative process that can lead to the creation of brand equity and brand value. The study proposes that marketing should link up with operations for managing critical activities in an environment that is sensitive to development and its costs.

\section{Implications for B2B Marketing}

The propositions suggest various implications for marketing practitioners and researchers. First, it explains how honest adoption and promotion of sustainability practices can be interpreted as a brand value by B2B buyers. It explains why brand managers should review their reverse marketing strategy from the sustainability related operational capabilities of their company. The research propositions reflect on the ability of brands to use initiatives such as recycling in a way that creates value for B2B customers and increases the market share of the brand. However, it is necessary to conduct future research on this topic from the procurement perspective of industrial purchases as well considering previous research studies. Therefore, loyal B2B customers become critical actors in using sustainability initiatives such as recycling to position the brand better than its competitors. Various kinds of sustainability based B2B engagements will help brand managers to acquire a larger share of the market. One example of such an activity would be the incentives attached to the purchase and sale of refurbished products. While B2B customers assist the brand in the implementation of eco-friendly strategies through reverse marketing, with access to local low-cost resources such as infrastructure and the skilled manpower required to repair and refurbish old products as per the quality standards of the brand, and allow brand managers to gain access to the location analytics and access to those segments 
interested in recycled products, these practices diminish the importance of loyalty generated by the brand.

Given that the propositions made are among the initial efforts to understand reverse marketing as a collective effort of the brand and its B2B customers, its role in determining brand value and brand equity needs to be validated by operationalizing and quantifying the variables in the model. Third, although considerable research has been conducted on reverse marketing and the resale of used products, the types of firms, their demographic information and work processes, investment capability and profits-related information needs to be reviewed and discussed. Fourth, this paper argues and defends the intention of brand managers to weave sustainability initiatives into their business practices, and pushes the boundaries of existing literature in following ways:

Sustainability as an Antecedent of Reverse Marketing: This study extends the scope of sustainability theory by linking it with the activities of the reverse marketing of branded products to its three dimensions: (1) economic for profitability, (2) social for an improved customer base, and (3) environmental for promoting recycling. It uses the findings of Dauvergne and Lister (2011) to recommend practices of reverse marketing for improving the business performance and use of a brand to promote recycled products. The arguments presented in the previous sections will permit future researchers to make detailed assumptions about the causality that exists between the different variables discussed in this paper.

Brand-driven Reverse Marketing: This study introduces the concept that the use of a brand name can facilitate the adoption of reverse marketing for used products in comparison to products that are offered without using a brand name. We use the explanation of reverse marketing provided by Marquardt et al. (2011) as an activity managed by a company to promote sustainability. 
Therefore, we define it as an outcome activity of the intent of a brand to adopt sustainabilitydriven business practices. We also describe why it is important to relate the arguments to the adoption of reverse marketing for recycling to the segmentation and positioning strategies adopted by a brand. The relationships conceptualised between the constructs are based on the knowledge that reverse marketing positions the firm above its competitors by fulfilling different types of needs of different segments, and positions the brand as a sustainability-oriented brand.

Brand Value for B2B Customers: We extend the current understanding about brand value for business customers by conceptualising the value created through reverse marketing based on the following components: (1) its influence on the capability of the brand to serve a larger share of the market and build its customer equity, (2) its influence on the business of the B2B customer by providing opportunities of growth, and (3) its influence on the revenue earned and profit gained by $\mathrm{B} 2 \mathrm{~B}$ customers through the purchase and sale of recycled products. The concept underlying the propositions is that used products acquired for recycling provide profit making opportunities for both the brand and its B2B customers.

Brand Equity for B2B Customers: We also discuss how reverse marketing drives brand equity by assuring $\mathrm{B} 2 \mathrm{~B}$ customers about the value that the brand will contribute to their business based on its differentiation and credibility in the marketplace. The arguments presented reflect how sustainability-driven reverse marketing positions the brand in a leadership spot based on the loyalty it gains based on the experiences of B2B customers about the value they receive from the brand. In order to address such opportunities, B2B firms actively participate in the conversion of the pre-owned product to make it saleable again and so improve the customer equity of the brand. 
Recycling as a sustainability initiative can result in improved earnings and business growth. The three factors - customer equity, growth and profitability - together can also improve cooperation and make business customers committed and loyal to the brand. The overall logic presented here is that reverse marketing as a sustainability-related business practice, when managed to create brand value for business customers, offers an improvement in brand equity. Brand equity thus generated in turn pushes brand managers to create better brand value that will keep the brand in a leadership position and engage both business customers and consumers.

\section{Future Research}

Managing waste by a company that operates internationally through a network of business-tobusiness customers is a very complex issue. Our research agenda asserts on the engagement of B2B customers into management of waste for the achievement of sustainability objectives through the implementation of reverse marketing, but it does not reflect on the type of benefits two firms will earn from recycling. Some of the issues related to the propositions, such as quality checks or quality control, also require further investigation. Other areas that need attention are the business relationships or buyer-seller agreements between B2B customers with competitor brands. The criticality of these issues can also be understood by reviewing the business practices of brands that use their B2B customers as a channel for supply by acquiring used products and supplying recycled products. Further issues, stemming from the latest research in marketing, are the cost effectiveness of local brands on the reverse marketing practices of international brands, and the identification of the variables that influence the competitiveness of a brand in a market where the brand value created for the B2B customers that sell value products rather than volume products for catering to a higher income group should justify the investment 
that $\mathrm{B} 2 \mathrm{~B}$ customers make in selling the product. The brand value for $\mathrm{B} 2 \mathrm{~B}$ customers serving the low income groups with volume products should function efficiently, and products should be priced appropriately (Viswanathan et al., 2009).

\section{Conclusion}

This paper contributes to the ongoing debate about sustainability, and presents reverse marketing as an honest outcome of the intention of a brand to adopt the sustainability initiative of waste management through recycling. It extends the current understanding about reverse marketing by explaining the role it plays in creating brand value for B2B customers by engaging them in a way that contributes to the overall equity of the brand in a market. The framework proposed, provides a theoretical toolbox that can be used by the manufacturers of brands. Author highlights the need for scholarly attention to this area of research. The implications of the research are presented and future research is recommended.

\section{Bibliography:}

Arruda, W. (2009). Brand communication: the three Cs. Thunderbird International Business Review, 51(5), 409-416.

Amit, R. and Zott, C. (2001), Value creation in e-business, Strategic Management Journal, 22(6/7): 493-520.

Babarinde, O. A. (2009). Bridging the economic divide in the Republic of South Africa: A corporate social responsibility perspective. Thunderbird International Business Review, 51(4), 355-368.

Biemans, W.G., Brand, M.J. (1995), Reverse marketing: A synergy of purchasing and relationship marketing, Journal of Supply Chain Management, 31(3), 28-37.

Calderon, H., Cervera, A., and Molla, A. (1997), Brand assessment: A key element of marketing strategy, Journal of Product and Brand Management, 6(5), 293-304.

Carter, C.R. and Ellarm, L.M. (1998), Reverse logistics: A review of literature and framework for further investigation, Journal of Business Logistics, 19(1): 85-102.

Chaerul, M., Fahruroji, A. R., \& Fujiwara, T. (2014). Recycling of plastic packaging waste in Bandung City, Indonesia. Journal of Material Cycles and Waste Management, 16(3), 509518.

Chaudhuri, A., Holbrook, M.B. (2001), The chain of effects from brand trust and brand affect to brand performance: the role of brand loyalty, Journal of Marketing, 81-93.

Chave, J. (2003), Public procurement, Business Law Review: 1. 
Chung, C., Chatterjee, S.C., Sengupta, S. (2012), Manufacturers' reliance on channel intermediaries: Value drivers in the presence of a direct web channel, Industrial Marketing Management, 41(1), 40-53.

Closs, D.J., Speier, C., Meacham, N. (2011), Sustainability to support end-to-end value chains: The role of supply chain management, Journal of the Academy of Marketing Science, 39(1), $101-116$.

Cox, A. (2004), Business relationship alignment: On the commensurability of value capture and mutuality in buyer and supplier exchange, Supply Chain Management: An International Journal, 9(5), 410-420.

Crittenden, V.L., Crittenden, W.F., Ferrell, L.K., Ferrell, O.C. and Pinney, C.C. (2011), Marketoriented sustainability: A conceptual framework and propositions, Journal of the Academy of Marketing Science, 39(1): 71-85.

Cruz-Rivera, R., Ertel, J. (2009), Reverse logistics network design for the collection of end-oflife vehicles in Mexico, European Journal of Operational Research, 196(3), 930-939.

da Cruz, N. F., Ferreira, S., Cabral, M., Simões, P., \& Marques, R. C. (2014). Packaging waste recycling in Europe: is the industry paying for it?. Waste management, 34(2), 298-308.

Dauvergne, P., Lister, J. (2011), Big brand sustainability: Governance prospects and environmental limits, Global Environmental Change, Article in Press. Available at weblink http://www.academia.edu/1113739/Big_Brand_Sustainability_Governance_prospects_and_en vironmental_limits (downloaded 14 November 2012).

Environmental Reporter (2013), LG cuts carbon footprint, saves \$1M in six months: http://www.environmentalleader.com/2013/07/26/lg-cuts-carbon-footprint-saves-1m-in-sixmonths/, downloaded on 26.07.2013.

Faisal, M.N. (2010), Sustainable supply chains: a study of interaction among the enablers, Business Process Management Journal, 16(3), 508-529.

Fraj, E., Martínez, E., Matute, J. (2013), Green marketing in B2B organisations: An empirical analysis from the natural-resource-based view of the firm, Journal of Business and Industrial Marketing, 28(5), 396-410.

Freires, F. G. M. (2014). Towards an investigation on the determinants for effectiveness and efficiency of reverse logistics systems (RLS). Independent Journal of Management \& Production, 5(1), 045-064.

Gobbi, C. (2008), The reverse supply chain: configuration, integration and profitability, Integration The Vlsi Journal. ISBN: 978-87-90855-10-9.

Goldfarb, A., Lu, Q., and Moorthy, S. (2009), Measuring brand value in an equilibrium framework, Marketing Science, 28(1), 69-86.

Gremler, D.D., Brown, S.W. (1999), The loyalty ripple effect: Appreciating the full value of customers, International Journal of Service Industry Management, 10(3): 271-291.

Grewal, D., Iyer, G.R., Levy, M. (2004), Internet retailing: Enabler, limiter and consequences, Journal of Business Research, 57(7): 703-713.

Guide, V.D.R. Jr., Jayaraman, V., Linton, J.D. (2003), Building contingency planning for closedloop supply chains with product recovery, Journal of Operations Management, 21(3), 259279.

Gupta, S. and Kumar, V. (2012), Sustainability as corporate culture of a brand for superior performance, Journal of World Business, 48(3).

Gupta, S., Malhotra, N.K. (2013), Marketing innovation: A resource-based view of international and local firms, Marketing Intelligence and Planning, 31(2). 
Handfield, R.B., C. Bechtel (2002), The role of trust and relationship structure in improving supply chain responsiveness, Industrial Marketing Management 31(4): 367-382.

Hazen, B.T., Cegielski, C., Hanna, J.B. (2011), Diffusion of green supply chain management: Examining perceived quality of green reverse logistics, International Journal of Logistics Management, 22(3): 373-389.

T. Hazen, B., Huscroft, J., J. Hall, D., K. Weigel, F., \& B. Hanna, J. (2014). Reverse logistics information system success and the effect of motivation.International Journal of Physical Distribution \& Logistics Management, 44(3), 201-220.

Henderson, J.C., and Venkatraman, N. (1993), Strategic alignment: Leveraging information technology for transforming organizations, IBM Systems Journal, 32(1), 4-16.

Høgevold, N.M., Svensson, G. (2012), A business sustainability model: A European case study, Journal of Business and Industrial Marketing, 27(2), 142-151.

Hunt, S.D., Morgan, R.M. (1996), The resource-advantage theory of competition: Path dependencies and evolutionary dimensions, Journal of Marketing, 60(4): 107-114.

Isdell, N. (2010). Connected capitalism: How business can tackle twenty-first-century challenges. Thunderbird International Business Review, 52(1), 5-12.

Keller, K.L. (1993), Conceptualising, measuring and managing customer-based brand equity, Journal of Marketing, 57(1): 1-22.

Krikke, H., Bloemhof-Ruwaard, J., Van, L.N. (2003), Concurrent product and closed loop supply chain design with an application to refrigerators, International Journal of Production Research, 41(16): 3689-3719.

Kumar, V., Jones, E., Venkatesan, R., Leone, R.P. (2011), Is market orientation a source of sustainable competitive advantage or simply the cost of competing?, Journal of Marketing, 75(1), 16-30.

Lapierre, J. (2000), Customer-perceived value in industrial contexts, Journal of Business and Industrial Marketing, 15(2/3): 122-145.

Leenders, M.R., Blenkhorn, D.L. (1988), Reverse Marketing: The New Buyer-Supplier Relationship, The Free Press, New York.

Lehr, Christian B., Jörn-Henrik Thun, and Peter M. Milling. "From waste to value-a system dynamics model for strategic decision-making in closed-loop supply chains." International Journal of Production Research 51.13 (2013): 4105-4116.

Levine, S. and White, P. (1961), Exchange as a conceptual framework for the study of interorganisational relationships, Administrative Science Quarterly, 5(4): 583-601.

Liang, Y. (2006), The construction of suppliers' coordination system in Chinese manufacturers based on reverse marketing theory, Journal of Beijing Technology and Business University (Social Science), 1, 012.

Linton, J.D., Klassen, R. \& Jayaraman, V. (2007). Sustainable supply chains: An introduction, Journal of Operations Management, 25(6): 1075-1082.

Long, J. C. (2008). From Cocoa to CSR: Finding sustainability in a cup of hot chocolate. Thunderbird International Business Review, 50(5), 315-320.

Mai, E., Chen, H. and Anselmi, K. (2012), The role of returns management orientation, internal collaboration and information support in reverse logistics, Journal of Transportation Management, 23(1): 45-59.

Marquardt, A.J., Golicic, S.L. and Davis, D.F. (2011), B2B services branding in the logistics services industry, Journal of Services Marketing, 25(1): 47-57. 
Mascarenhas, B., \& Koza, M. P. (2008). Develop and nurture an international alliance capability. Thunderbird International Business Review, 50(2), 121-128.

Meade, L., Sarkis, J., Presley, A. (2007), The theory and practice of reverse logistics, International Journal of Logistics Systems and Management, 3(1), 56-84.

Menon, A., Menon, A. (1997), Enviropreneurial marketing strategy: The emergence of corporate environmentalism as market strategy, Journal of Marketing, 61(1): 51-67.

Menon, A., Menon, A., Chowdhury, J., Jankovich, J. (1999), Evolving paradigm for environmental sensitivity in marketing programs: A synthesis of theory and practice, Journal of Marketing Theory and Practice, 1-15.

Miles, R.E., C.C. Snow (1978), Organizational Strategy, Structure and Process, New York: McGraw-Hill.

Norek, C.D. (2003), Throwing it into reverse, DC Velocity 1(1): 54-58.

Olson, E.M., Slater, S.F., Hult, G.T.M. (2005), The performance implications of fit among business strategy, marketing organization structure, and strategic behaviour, Journal of marketing, 49-65.

Park, J., Sarkis, J., Wu, Z. (2010), Creating integrating business and environmental value within the context of China's circular economy and ecological modernisation, Journal of Cleaner Production, 18(15): 1494-1501.

Parkes, C., \& Borland, H. (2012). Strategic HRM: Transforming Its Responsibilities Toward Ecological Sustainability-The Greatest Global Challenge Facing Organizations. Thunderbird International Business Review,54(6), 811-824.

Porter, M.E. (1980), Competitive Strategy, New York: The Free Press.

Pressey, A., Tzokas, N., Winklhofer, H. (2007), Strategic purchasing and the evaluation of "problem" key supply relationships: What do key suppliers need to know?, Journal of Business and Industrial Marketing, 22(5), 282-294.

Quayle, M. (2002). Purchasing policy in Switzerland: An empirical study of sourcing decisions. Thunderbird International Business Review, 44(2), 205-236.

Raggio, R.D., Leone, R.P. (2007), The theoretical separation of brand equity and brand value: Managerial implications for strategic planning, Journal of Brand Management, 14(5): 380395.

Rese, M. (2006), Successful and sustainable business partnerships: How to select the right partners, Industrial Marketing Management, 35(1), 72-82.

Richey, R.G., Genchev, S.E., Daugherty, P.J. (2005), The role of resource commitment and innovation in reverse logistics performance, International Journal of Physical Distribution and Logistics Management, 35(4): 233-257.

Rosen, C. M., Beckman S.L. and Bercovitz J. (2002), The role of voluntary industry standards in environmental supply-chain management, Journal of Industrial Ecology 6(3-4): 103-123.

Salzman, J. (1997), Sustainable consumption and the law, Environmental. Law. 27: 1243.

Sarkar, A.N. (2012), Green branding and eco-innovations for evolving a sustainable green marketing strategy, Asia-Pacific Journal of Management Research and Innovation, 8(1), 3958.

Schau, H.J., Muniz A.M. and Amould E.J. (2009), How brand community practices create value, Journal of Marketing 73(5): 30-51.

Schiele, H., Veldman, J., Hüttinger, L. (2011), Supplier innovativeness and supplier pricing: The role of preferred customer status, International Journal of Innovation Management, 15(01), $1-27$. 
Seshadri, S. (2013), The sustainability syndicate: Shared responsibility in a trans-organizational business model, Industrial Marketing Management, In Press

Seuring, S., Sarkis, J., Muller, M., Rao, P. (2008), Sustainability and supply chain management an introduction to the special issue, Journal of Cleaner Production, 16(15): 1545-1551.

Sharma, A. (2002). Trends in Internet-based business-to-business marketing.Industrial marketing management, 31(2), 77-84.

Sharma D. (2011). Rise, Fall and rise of IBM in India, Weblink downloaded on $14^{\text {th }}$ February 2015 from http://businesstoday.intoday.in/story/ibm-india-george-fernandes-history-inindia/1/16367.html

Sharma, A., \& Sheth, J. N. (2004). Web-based marketing: the coming revolution in marketing thought and strategy. Journal of Business Research, 57(7), 696-702.

Sharma, A., Iyer, G.R., Mehrotra, A., Krishnan, R. (2010), Sustainability and business-tobusiness marketing: A framework and implications, Industrial Marketing Management, 39(2): 330-341.

Sheth, J.N. (1973), A model of industrial buyer behavior. Journal of Marketing, 37(4): 50-56.

Sheth, J.N. (2011). Impact of emerging markets on marketing: Rethinking existing perspectives and practices. Journal of Marketing, 75(4), 166-182.

Sheth, J.N., Sethia, N.K. and Srinivas, S. (2011), Mindful consumption: A customer-centric approach to sustainability, Journal of the Academy of Marketing Science, 39: 21-39.

Sirgy, M.J., and Lee, D.J. (2008), Well-being marketing: An ethical business philosophy for consumer goods firms, Journal of Business Ethics, 77(4), 377-403.

Slater, S.F., and Narver, J.C. (1995), Market orientation and the learning organization, Journal of Marketing, 63-74.

Steenkamp, J.E.M. and Hofstede, F.T. (2002), International market segmentation: Issues and perspectives, International Journal of Research in Marketing, 19(3): 185-213.

Stock, J.R., Speh, T.W., Shear, L.H. (2002), Many happy (product) returns. Harvard Business Review, 80(7): 16-17.

Tang, C.S. (2010), A review of marketing-operations interface models: From co-existence to coordination and collaboration, International Journal of Production Economics, 125(1), 2240.

Tixier, M. (2003). Soft vs. hard approach in communicating on corporate social responsibility. Thunderbird International Business Review, 45(1), 71-91.

Tixier, M. (2005). Globalization and localization of contents: Evolution of major internet sites across sectors of industry. Thunderbird International Business Review, 47(1), 15-48.

Viswanathan, M., Seth, A., Gau, R. and Chaturvedi, A. (2009), Ingraining product-relevant social good into business processes in subsistence marketplaces: The sustainable market orientation, Journal of Macromarketing, 29(4): 406-425.

Webster, F.E. (2000), Understanding the relationships among brands, consumers and resellers, Journal of the Academy of Marketing Science, 28(1): 17-23.

Wei, D., Wang, Y. Y., \& Ju, Y. Y. (2014). A research on the competition mode of electronic waste recycling. Environmental Science and Biological Engineering, 156, 145

Wong, A., Dean, A. (2009), Enhancing value for Chinese shoppers: The contribution of store and customer characteristics, Journal of Retailing and Consumer Services, 16(2): 123-134.

Ylä-Mella, J., Poikela, K., Lehtinen, U., Keiski, R. L., \& Pongrácz, E. (2014). Implementation of waste electrical and electronic equipment directive in Finland: evaluation of the collection 
network and challenges of the effective WEEE management. Resources, Conservation and Recycling, 86, 38-46 
Figure 1: Conceptual Framework

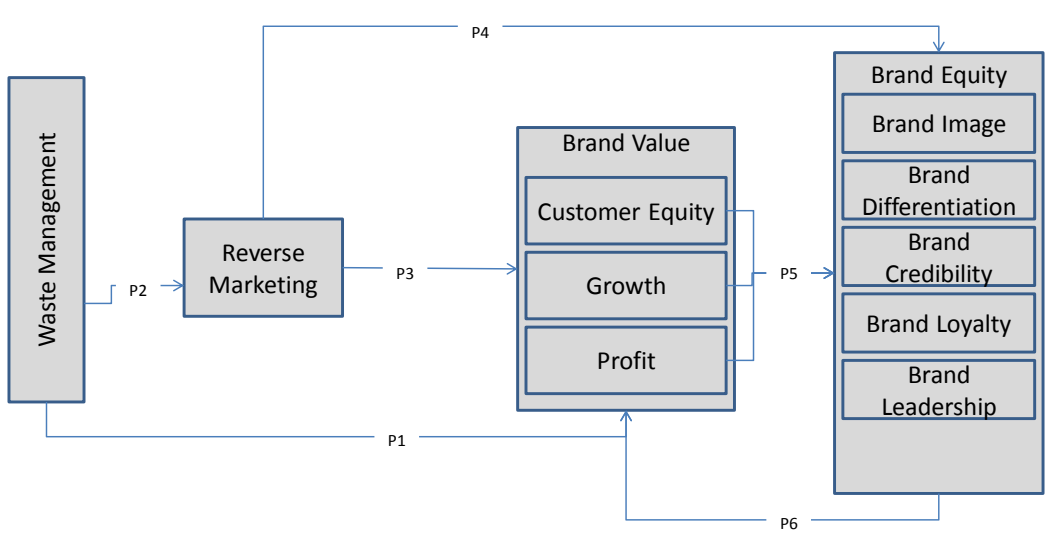


Figure 2: Reverse Marketing

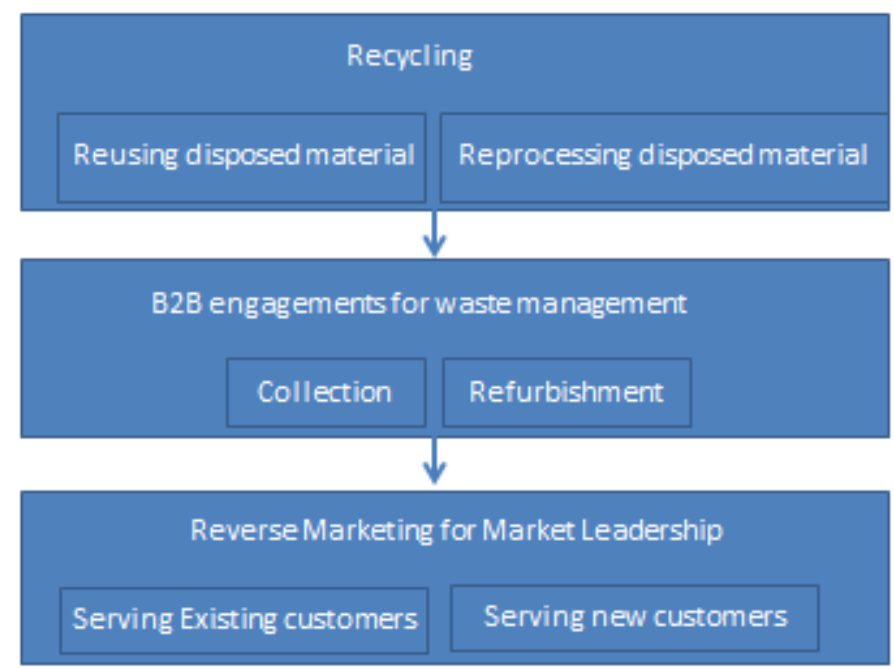

